Article available at http://www.parasite-journal.org or nttp://dx.dol.org/10.1051/parasite/2003101p39

\title{
The tReATMENT OF Plasmodium falCIPARUM-INFECTED ERYTHROCYTES WITH CHLOROQUINE LEADS TO ACCUMULATION OF FERRIPROTOPORPHYRIN IX BOUND TO PARTICULAR PARASITE PROTEINS AND TO THE INHIBITION OF THE PARASITE'S 6-PHOSPHOGLUCONATE DEHYDROGENASE
}

FAMIN O.* \& GINSBURG H.*

\section{Summary:}

Ferriprotoporphyrin IX (FPIX) is a potentially toxic product of hemoglobin digestion by intra-erythrocytic malaria parasites. It is detoxified by biomineralization or through degradation by glutathione. Both processes are inhibited by the antimalarial drug chloroquine, leading to the accumulation of FPIX in the membranes of the infected cell and their consequent permeabilization. It is shown here that treatment of Plasmodium falciparum-infected erythrocytes with chloroquine also leads to the binding of FPIX to a subset of parasite proteins. Parasite enzymes such as aldolase pyrimidine nucleoside monophosphate kinase and pyrimidine 5'nucleotidase were inhibited by FPIX in vitro, but only the activity of 6-phosphogluconate dehydrogenase was reduced significantly in cells after drug treatment. Additional proteins were extracted from parasite cytosol by their ability to bind FPIX. Sequencing of these proteins identified heat shock proteins 90 and 70 , enolase, elongation factor $1-\alpha$, phoshoglycerate kinase, glyceraldehyde 3phosphate dehydrogenase, L-lactate dehydrogenase and gametocytogenesis onset-specific protein. The possible involvement of these proteins in the antimalarial mode of action of chloroquine is discussed. It is concluded that drug-induced binding of FPIX to parasite glycolytic enzymes could underlie the demonstrable inhibition of glycolysis by chloroquine. The inhibition of 6 phosphogluconate dehydrogenase could explain the reduction of the activity of the hexose monophosphate shunt by the drug Inhibition of both processes is deleterious to parasite survival. Binding of FPIX to other proteins is probably inconsequential to the rapid killing of the parasite by chloroquine.

KEY WORDS : malaria, Plasmodium falciparum, chloroquine, ferriprotoporphyrin IX, protein binding, enzyme inhibition.

MOTS CLÉS : malaria, Plasmodium falciparum, chloroquine, ferriprotoporphyrine IX, liaison aux protéines, inhibition d'enzymes.
Résumé : L'ACTION DE LA CHLOROQUINE SUR DES ÉRYTHROCYTES INFECTÉS PAR PLASMODIUM FALCIPARUM CONDUTT À UNE ACCUMULATION DE FERRIPROTOPORPHYRINE IX LLÉE À DES PROTÉINES PARASITAIRES ET À UNE INHIBITION DE LA 6-PHOSPHOGLUCONATE DÉHYDROGÉNASE PARASITAIRE

La ferriprotoporphyrine IX (FPIX) est un produit potentiellement toxique issue de la digestion de l'hémoglobine par les parasites intraérythrocytaires de la malaria. FPIX est détoxifié par biominéralisation ou par dégradation par le glutathion. Les deux processus sont inhibés par la drogue antipaludique, la chloroquine, menant à l'accumulation de FPIX dans les membranes de la cellule infectée et par conséquent à sa perméabilisation. Nous montrons dans ce travail que le traitement d'érythrocytes infectés par

Plasmodium falciparum mène aussi à la liaison de FPIX à une souspopulation de protéines parasitaires. Des enzymes parasitaires telles que l'aldolase, la pyrimidine nucléoside monophosphate kinase ou la pyrimidine 5'nucléotidase sont inhibées par FPIX in vitro. Cependant, seule l'activité de 6-phosphogluconate déhydrogénase est réduite d'une manière significative dans les cellules traitées. D'autres protéines du cytosole parasitaire présentent de l'affinité pour FPIX. Le séquençage de ces protéines a permis d'identifier les protéines heat shock 70 et 90, l'énolase, le facteur d'élongation $7-\alpha$, la phosphoglycérate kinase, la glycérladhéyde 3-phosphate déhydrogénase, la Llactate déhydrogénase et la protéine specifique de la mise en place (onset specific) de la gamétocytogenèse. L'implication possible de ces protéines dans le mode d'action antipaludique de la chloroquine est discuté. Nous concluons que la liaison - induite par la drogue - de FPIX aux enzymes glycolytiques du parasite pourraient être responsable de l'inhibition démontrable de la glycolyse par chloroquine. L'inhibition de la b-phosphogluconate déhydrogénase pourrait expliquer la réduction de l'activité de la voie de l'hexose monophosphate par la drogue. L'inhibition des deux processus est pernicieuse à la survie du parasite. La liaison de FPIX à d'autres protéines n'a probablement pas de conséquences

concernant la mort rapide du parasite provoquée par chloroquine.

\section{INTRODUCTION}

T ntraerythrocytic malaria parasites ingest and digest the cytosol of their host cells (Yayon et al., 1984; Lrancis et al., 1997). Ferriprotoporphyrin IX (FPIX)

Abbreviations used: AQ : amodiaquine; CQ : chloroquine; FPIX : ferriprotoporphyrin IX; GSH : glutathione; HMS : hexose monophosphate shunt; $\mathrm{MQ}$ : mefloquine; $\mathrm{Q}$ : quinine.

* Department of Biological Chemistry, Institute of Life Sciences, The Hebrew University of Jerusalem, Jerusalem 91904, Israel.

Correspondence: Prof. Hagai Ginsburg

Tel. +972-2-658-5539 - Fax: +972-2-658-5440.

E-mail: hagai@vms.huji.ac.il is a toxic product of this process. The erythrocyte cytosol comprises essentially hemoglobin, and the parasite must detoxify FPIX. This is achieved both by its biomineralization into hemozoin (Goldberg \& Slater, 1992) and by its degradation by glutathione (GSH) after it has left the food vacuole into the parasite cytosol (Atamna \& Ginsburg, 1995; Ginsburg et al., 1998). Chloroquine (CQ) inhibits both processes. Recent findings indicate that treatment of Plasmodium falciparum-infected erythrocytes with $\mathrm{CQ}$ increases the content of FPIX in the membrane fraction of the cells (Ginsburg et al., 1998; Zhang et al., 1999). Whereas this increase could lead to the permeabilization of the membrane and cell death, as attested by the correla- 
tion between membrane-associated FPIX and parasite killing, the pharmacological action of CQ is thought to be pleiotropic. Hence, other targets in the cell may be affected by free or CQ-associated FPIX and thus be either a primary or an adjunct target for drug action. Due to its amphipathic nature, FPIX can bind non-specifically to proteins. Several erythrocyte enzymes have been shown to be inhibited by FPIX (Zerez et al., 1987): aldolase, a key enzyme of glycolysis that provides metabolic energy to the parasite; 6-phosphogluconate dehydrogenase, a key enzyme in the hexose monophosphate shunt that provides reducing equivalents to counteract oxidative stress; adenylate kinase, instrumental in purine metabolism; pyrimidine nucleoside monophosphate kinase, involved in pyrimidine nucleoside synthesis; and pyrimidine 5'-nucleotidase which functions in the degradation of pyrimidine and purine nucleotides. The inhibitory constants of FPIX on the activity of all these enzymes were reported to be $\approx 1 \mu \mathrm{M}$.

The present investigation aims to elucidate the effects of FPIX on these enzymes in the parasite, to detect additional parasite proteins that bind FPIX and to assess if indeed inhibition of the function of these proteins could contribute to the antimalarial mode of action of $\mathrm{CQ}$.

\section{MATERIALS AND METHODS}

\section{MATERIALS}

$\mathrm{F}$ resh $\mathrm{O}^{+}$or $\mathrm{A}^{+}$blood and human $\mathrm{O}^{+}$or $\mathrm{A}^{+}$plasma were kindly donated by the Hadassah Hospital
Blood Bank. RPMI-1640 was purchased from Biological Industries, Kibbutz Bet Haemek, Israel. Hemin-agarose beads, ATP, AMP, NADP, NADH, fructose-2,6-bisphosphate (K salt), 6-phosphogluconic acid, pyruvate kinase-lactate dehydrogenase mixture and all enzymes used in this investigation were purchased from Sigma Chemical Co. Chloroquine diphosphate was obtained from Serva. Amodiaquine dihydrochloride and quinine hydrochloride were purchased from Sigma Chemical Co. Mefloquine was generously provided by A.F. Cowman. Hemin was obtained from Porphyrin Products, Logan, UT. GELCODE blue stain was purchased from PIERCE (lot no: 981221169). All other chemicals were of the best available grade.

\section{PARASITE CULTIVATION}

The FCR3 strain of P. falciparum was cultivated as previously described (Zhang et al., 1999) in RPMI-1640 medium supplemented with $10 \mathrm{mM}$ glucose, $25 \mathrm{mM}$ $\mathrm{NaHCO}_{3}, 25 \mathrm{mM}$ Hepes and $10 \%$ human heat-inactivated plasma. Cultures were synchronized by the sor- bitol technique (Lambros \& Vanderberg, 1979) using the less toxic alanine. Parasites were fractionated to different stages using the Percoll-alanine gradient centrifugation protocol (Kutner et al., 1985).

\section{EFFECT OF DRUG TREATMENT \\ ON THE FERRIPROTOPORPHYRIN IX LEVEL \\ IN PARASITE CYTOPLASM}

Synchronized cultures were seeded at the ring stage and allowed to grow for another 20 hour until most parasites reached the trophozoite stage. Parasitemia and cell number were determined, and cells were cultured for three-four hours in absence or the presence of $10 \mu \mathrm{M}$ drug. Thereafter, cultures were washed twice in wash medium (culture medium without plasma, $37^{\circ} \mathrm{C}$ ) to remove the drug, and cells were used for the determination of FPIX levels in the cytoplasm of the parasite, for the identification of parasite FPIX- binding proteins and for measurement of the activity of enzymes known to be inhibited by FPIX, as described below.

\section{PreParation of FREE PARASITES FROM CULTURES}

Trophozoite-infected erythrocytes were enriched by Percoll-alanine gradient centrifugation to $>90 \%$ parasitemia. Parasites were released from infected RBC by saponin lysis $(0.003 \%$ saponin $(\mathrm{w} / \mathrm{v})$ in PBS) followed with repeated washes in PBS buffer (1,500 $\mathrm{xg}$ for five minutes) until no hemoglobin could be detected in the wash solution (Zhang et al., 1999). The free parasites were resuspended in an equal volume of buffer $(0.1 \mathrm{M}$ $\mathrm{KCl}$ in $20 \mathrm{mM}$ Na-phosphate, $\mathrm{pH}$ 7.4).

\section{THE ISOLATION OF PARASITE PROTEINS FROM INFECTED CELLS}

Free parasites were disrupted by five cycles of freezing in liquid nitrogen and thawing at $37^{\circ} \mathrm{C}$. The cell debris and hemozoin were spun down by centrifugation at $10,000 \mathrm{xg}$ for 15 minutes. The lysate was dissolved in twice concentrated sample buffer containing $2 \%$ SDS, $10 \%$ glycerol in $63 \mathrm{mM}$ Tris-Cl buffer pH 6.8 (volume ratio 1:1).

\section{STAINING OF FPIX ON SDS GELS}

Samples of parasite cytoplasm were run on SDS-PAGE (10\% polyacrylamide) omitting dithiotreitol from the running buffer in order to avoid destruction of FPIX. Gels were fixed for 20 minutes with $12.5 \%$ trichloroacetic acid and washed for 20 minutes in double distilled water. Gels were then stained with a mixture of $0.1 \%(\mathrm{w} / \mathrm{v})$ o-dianisidine chloride and $20 \mathrm{mM}$ hydrogen peroxide in $40 \mathrm{mM}$ citric acid until appearance of stained FPIX (Francis \& Becker, 1984).

For quantitative assessment of heme content, samples containing various amounts of FPIX bound to BSA 
were run in parallel with parasite samples. After staining, the gels were scanned (UMAX 1220 p scanner), a calibration curve was constructed from the areas of the FPIX-BSA bands and the integral of the bands from the parasite sample was used to calculate the amount of FPIX in the parasite samples normalized to the number of parasites present in the sample.

\section{ISOLATION OF FPIX BINDING PROTEINS FROM CELL LYSATES AND THEIR SEQUENCING}

Parasite cytosol was prepared as described above in $0.1 \mathrm{M} \mathrm{KCl}, 20 \mathrm{mM}$ Na-phosphate buffer $\mathrm{pH} 7.4$, and incubated with hemin-agarose beads (hemin concentration $5 \mu \mathrm{M}$ ) for two hours in the same buffer at $37^{\circ} \mathrm{C}$. Thereafter, the beads were spun down and the supernatant was discarded. The beads were washed five times with buffer: $1.0 \mathrm{M} \mathrm{KCl}, 20 \mathrm{mM} \mathrm{Na}$-phosphate $\mathrm{pH}$ 7.4. This concentration of KCL was chosen after it was ascertained that increasing $[\mathrm{KCl}]$ from 0.1 to $1.0 \mathrm{M}$ did not result in selective elution of protein bands, and that the majority of proteins remained associated with the beads after washing with $1.0 \mathrm{M} \mathrm{KCl}$ (data not shown). The bound proteins were eluted from the beads by incubation (for 15 minutes at near boiling temperature) with sample buffer: $2 \%$ SDS, $10 \%$ glycerol, $10 \mathrm{mM}$ DTT, $63 \mathrm{mM}$ TRIS-HCl, pH 6.8 (beads to buffer volume ratio $1: 1$ ). The samples were electrophoresed through an $8 \%$ TRIS-glycine acrylamide gel. The gel was washed five times with DDW for five hours and stained with Gelcode ${ }^{\circledR}$ Blue Stain (PIERCE, lot No. 981221169). Following destaining, the protein bands were cut-out and reduced with DTT $(5 \mathrm{mM})$ and carboxymethylated "in gel" using $10 \mathrm{mM}$ iodoacetamide. The gel was then further destained in $50 \%$ acetonotrile with $100 \mathrm{mM}$ ammonium bicarbonate, dried and rehydrated with $100 \mathrm{mM}$ ammonium bicarbonate $\mathrm{pH} 7.4$ containing modified trypsin (Promega). After overnight incubation at $37^{\circ} \mathrm{C}$ with shaking, the resulting peptides were eluted from the gel pieces with $60 \%$ acetonitrile containing $0.1 \%$ TFA and analyzed by LCMS. The MS and MS/MS data from the run were compared to the simulated proteolysis and fragmentation of the proteins in the "owl" database using the Sequest software (J. Eng \& J. Yates Univ. of Washington).

\section{MEASUREMENT OF ENZYME ACTIVITIES IN DIFFERENT COMPARTMENTS OF PARASITE-INFECTED RBC}

$P$. falciparum infected RBC (trophozoite stage) were isolated by Percoll-alanine gradient to obtain $\geq 90 \%$ parasitemia. Parasites were released from host cell by saponin lysis $(0.003 \%(\mathrm{w} / \mathrm{v})$ saponin, volume ratio $1 / 20$ ) followed by centrifugation at $4,5000 \mathrm{xg}$ for two minutes. The supernatant was collected for the determination of enzyme activity in the host cell compart- ment. Free parasites were washed five times in PBS buffer until no hemoglobin (absorbance at $412 \mathrm{~nm}$ ) could be detected in the supernatant.

Free parasites were disrupted by trituration (five times) through a 27 gauge needle at $4^{\circ} \mathrm{C}$ in $0.25 \mathrm{M}$ sucrose, 20 mM Na-phosphate buffer, pH 7.4 (Bray et al., 1999). This procedure prevents the disruption of food vacuoles and the possible degradation of cytosolic proteins by vacuolar proteases. The trituration mixture was centrifuged at $10,000 \times \mathrm{xg}$ for 10 minutes and the supernatant was collected for determination of parasite enzyme activity.

For the determination of enzyme activity in normal $\mathrm{RBC}$, cells were lysed in hypotonic $5 \mathrm{mM}$ phosphate buffer, $\mathrm{pH} 8$ at $4^{\circ} \mathrm{C}$.

Activity of aldolase, 6-phosphogluconate dehydrogenase and adenylate kinase was determined as described by Beutler (1984). Activity of pyrimidine-5'nucleosidase was determined according to the method of Zerez \& Tanaka (1985). Results were normalized to protein content in lysates and to the cell number in samples.

\section{BINDING OF FPIX TO PURE PROTEINS AND ENZYMES}

The following proteins were dissolved in PBS $(25 \mu \mathrm{g} / \mathrm{ml})$ : BSA, cytochrome c oxidase, hexokinase, alcohol dehydrogenase, GSH reductase, triose phosphate isomerase, $\alpha$-glycerophosphate dehydrogenase. Each protein or a mixture of all proteins was incubated with $50 \mu \mathrm{M}$ freshly prepared FPIX for 15 minutes at $37^{\circ} \mathrm{C}$, then separated by SDS-PAGE and stained for FPIX or in parallel with Coomassie.

\section{RESULTS}

\section{EFFECT OF DRUG TREATMENT ON THE BINDING} OF FPIX TO PROTEINS

R ather high drug concentrations relative to those known to inhibit parasite growth in culture were used in this investigation. Such high concentrations were chosen because it has been shown before that shorter times of exposure to the drugs required higher concentrations for inhibition of parasite growth (Krugliak \& Ginsburg, 1991). Treatment of infected cells with CQ or AQ resulted in the association of FPIX with several parasite proteins. These proteins were visualized after SDS-PAGE of disrupted free parasites and staining both with Coomassie and for FPIX (Fig. 1). The equal densities of the Coomassie bands in the various lanes (Fig. 1A) indicate that equal amounts of proteins were loaded in each lane and that the differences in intensities of the FPIX-stained bands (Fig. 1B) 
A

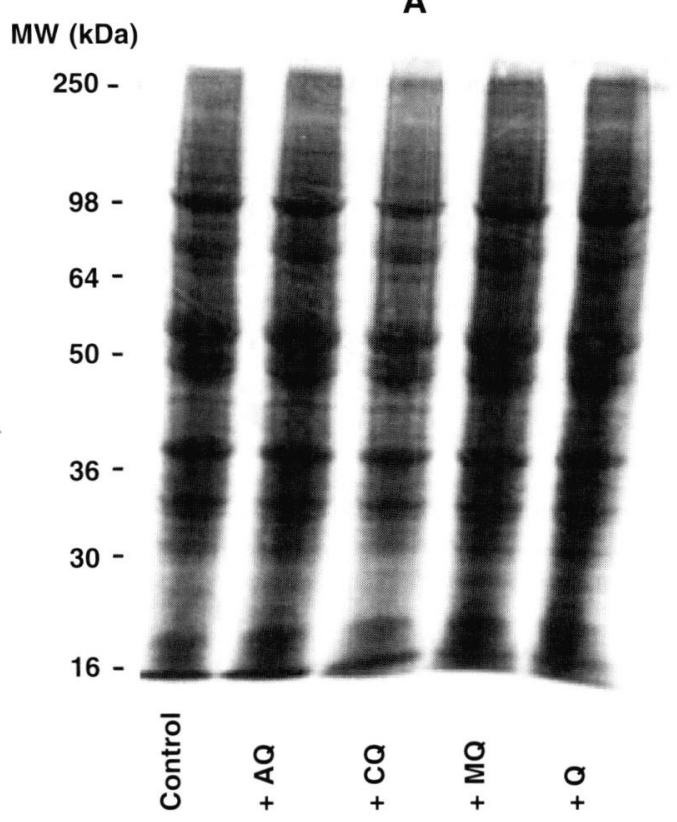

MW (kDa)

$250-$

98

50

50

$36-$

$30-$

$16-$
B

Fig. 1. - Association of FPIX with parasite proteins

Infected cells were treated for four hours with $10 \mu \mathrm{M} \mathrm{CQ}, \mathrm{AQ}, \mathrm{Q}$ or MQ. Parasites were freed and disrupted as described in Materials and Methods. The supernatant following centrifugation was run on SDS-PAGE and stained for proteins with Coomassie Blue (1A) and for FPIX (1B).

are a genuine reflection of selective FPIX binding. The identity of the Coomassie bands among the different treatments, suggest that drug treatment per se does induce or down regulates parasite proteins. Comparison of the Coomassie-stained gels with their FPIXstained counterparts clearly indicates that FPIX binding demonstrates varying specificity (the relative intensities of Coomassie bands and FPIX bands are distinctly different). The FPIX-associated proteins cannot be high molecular weight products of hemoglobin digestion since, under the conditions of the SDS-PAGE, hemoglobin tetramers are dissociated into monomers (ascertained using lysates of uninfected erythrocytes; data not shown). The FPIX-binding proteins are all of greater molecular weights than the hemoglobin monomer $(16.7 \mathrm{kDa})$ that are always present in the gels of CQtreated parasites. This represents the remnants of undigested hemoglobin in the free parasite (Famin \& Ginsburg, 2002). FPIX binding appears to be insignificant in drug-free parasites, rises to high levels after treatment of intact infected cells with either CQ or AQ, but is generally absent, or present at very low levels, after treatment with MQ. Treatment with Q result in lower levels than with CQ treatment but higher than with MQ treatment. The levels of protein-associated FPIX vary quite noticeably among experiments due to some variations in culture conditions and parasite stage, but the relative effect of the drugs is always observed. To confirm the presence of FPIX on these proteins, the extracts were treated with low concentrations of $\mathrm{H}_{2} \mathrm{O}_{2}$, known to degrade FPIX. This treatment considerably reduced the intensity of FPIX on all protein bands and almost destroyed it completely on the high molecular weight species (Fig. 2). The effects of verapamil, an enhancer of CQ action in resistant strains, including the FCR3 strain used in this investigation, and of $\mathrm{H}_{2} \mathrm{O}_{2}$, was also tested. The effect of CQ on the level of FPIX binding was enhanced by verapamil above that seen with CQ (Fig. 3). Since FPIX is the intracellular ligand for CQ (Bray et al., 1999), this increase may explain the ability of verapamil to increase the net uptake of CQ into drug-resistant strains. The presence of $\mathrm{H}_{2} \mathrm{O}_{2}$ reduced the effect of CQ. It is not clear why verapamil itself caused a slight increase in FPIX binding, but for that matter the mode of antimalarial action of this drug alone, is not known.

\section{TOTAL PROTEIN-BOUND FPIX IN CQ-TREATED INFECTED CELLS}

The quantification of FPIX bound to proteins, as revealed by specific staining, was accomplished using BSA as a prototypic protein. The intensity of the FPIX signal was correlated with the amount of loaded FPIX (data not shown). Integration of staining intensities of all protein bands associated with FPIX (after SDSPAGE of parasite cytosol following CQ treatment) in conjunction with staining intensities of known amounts of FPIX-BSA loaded on the same gel, allowed the cal- 
culation of total intact FPIX amount. This calculation yields a concentration of $\sim 165 \mu \mathrm{M}$ (based on the number of cells used for the preparation of free parasites, the number of infected cells/l and the relative volume

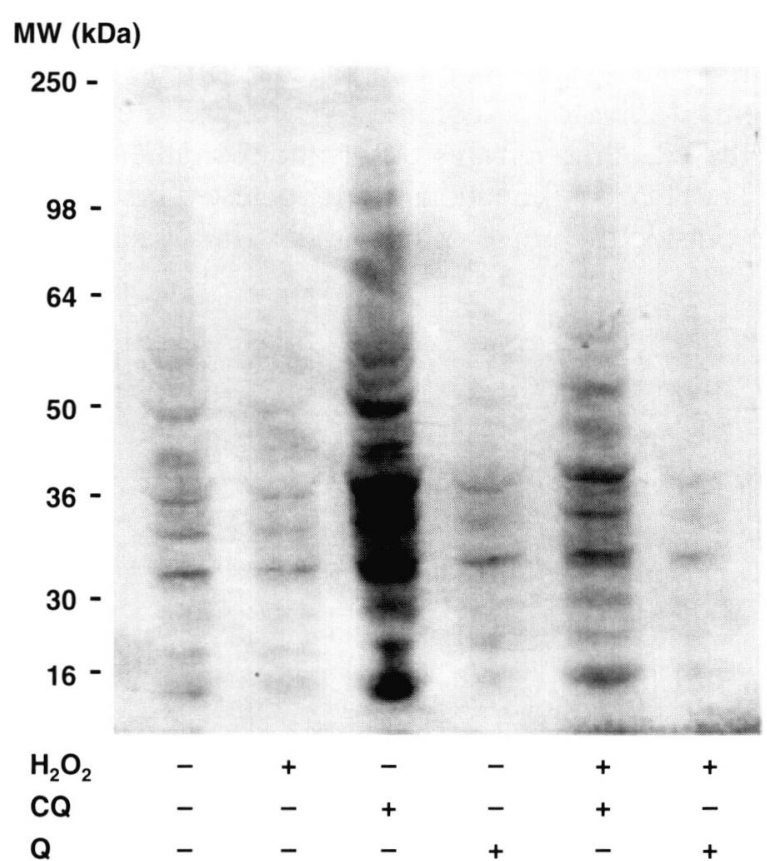

Fig. 2. - Assessment of FPIX as protein ligand.

Infected cells were treated with $10 \mu \mathrm{M} C Q$ or $Q$ for four hours. Free parasites were obtained by saponin lysis and disrupted. Parallel samples were left as controls or treated with $10 \mu \mathrm{M} \mathrm{H}_{2} \mathrm{O}_{2}$ for several minutes at room temperature, electrophoresed by SDS-PAGE and stained for FPIX. Band at $\sim 16 \mathrm{kDA}$ is hemoglobin monomers.

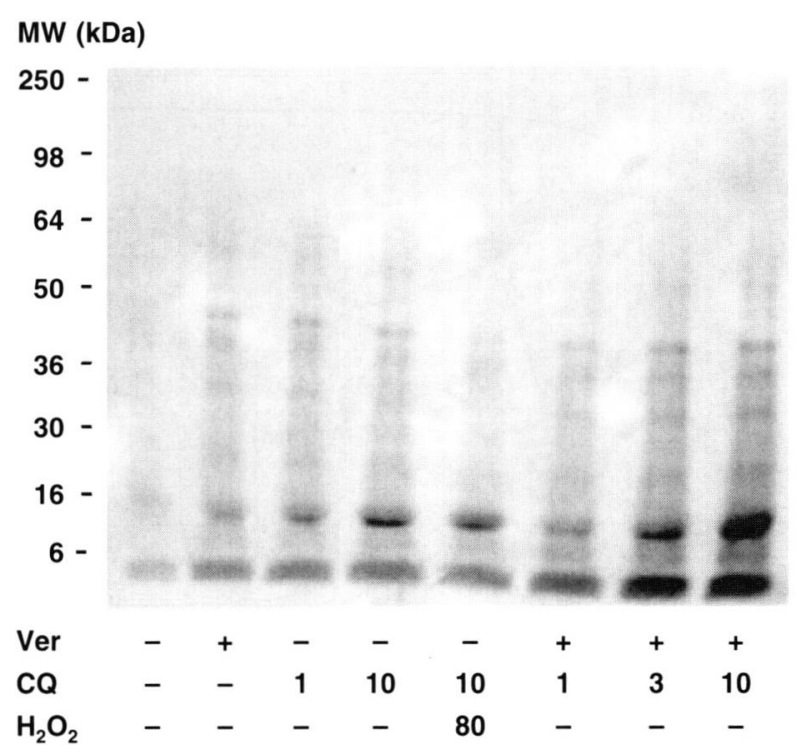

Fig. 3. - Effect of verapamil and $\mathrm{H}_{2} \mathrm{O}_{2}$ on CQ-induced association of FPIX with parasite proteins

Infected cells were incubated for four hours at conditions described in the legend to Figure 1 without or with increasing concentrations of $\mathrm{CQ} \pm 10 \mu \mathrm{M}$ verapamil, or with $\mathrm{CQ}+80 \mu \mathrm{M} \mathrm{H}_{2} \mathrm{O}_{2}$. Parasites were freed by saponin lysis, disrupted and the supernatant was electrophoresed on SDS-PAGE. Gels were stained for FPIX. of the parasite in the infected cell). This is a tiny fraction of the total $\sim 4 \mathrm{mM}$ FPIX that is generated up to the trophozoite stage during hemoglobin digestion and that is not polymerized into hemozoin. FPIX bound to parasite proteins is about half the amount found to be associated with the membrane fraction of similarly treated cells (Zhang et al., 1999).

\section{IDENTITY OF FPIX-BINDING PARASITE PROTEINS}

Since the parasite lysate contains many proteins (Fig. 1A) and their staining for FPIX resulted in broad diffuse bands (Fig. 1B), it was impossible to isolate the FPIX-binding proteins from the gels in pure form. An alternative way to identify FPIX-binding proteins in parasite cytosol was undertaken. Free parasites were disrupted by freezing and thawing and after centrifugation to remove cell debris and hemozoin, the lysate was equilibrated with FPIX-agarose beads. The unbound proteins were removed and bound proteins were eluted with sample buffer, electrophoresed

\section{MW (kDa)}

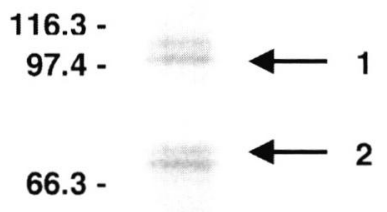

$55.4-$

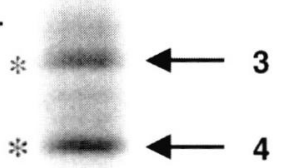

$36.5-$

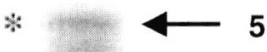

$25.1-$

Fig. 4. - Identification of parasite proteins that bind to hemin-agarose beads

Trophozoites were freed from host cells, triturated and the supernatant was exposed to hemin agarose beads as described in Material and methods. Bound proteins were electrophoresed and stained for identification. Individual bands were cut out from the gels and their proteins were sequenced. Identification of bands: 1 - Hsp90; 2 - Hsp70; 3 - enolase and elongation factor 1- $\alpha ; 4$ - phoshoglycerate kinase; 5 - glyceraldehyde 3 -phosphate dehydrogenase; 6 - Llactate dehydrogenase and gametocytogenesis onset-specific protein. Bands labeled with * are also seen in the lysates of CQ-treated cells (Fig. 1B). 
and stained with Coomassie (Fig. 4). The parasite lysate proteins that were eluted from the beads were probably bound non-specifically since their elution did not depend on ionic strength, i.e., the same proteins could be eluted with $0.1 \mathrm{M}$ and $1.0 \mathrm{M} \mathrm{KCl}$. No binding of lysate proteins could be observed with blank agarose beads. Some of the proteins that were eluted from the hemin agarose beads migrated on the gel identically to those found to bind FPIX in CQ-treated infected cells, notably those having $\sim 50, \sim 36$ and $\sim 39 \mathrm{kDa}$ molecular weight. While identical migration does not confirm identity of proteins, uniqueness may be suggested. Major bands were excised from the gel and sequenced. Several parasite proteins were thus detected: heat shock proteins 70 and 90 , enolase, phosphoglycerate kinase, glyceraldehyde 3phosphate dehydrogenase, L-lactate dehydrogenase and gamtocytogenesis onset-specific protein. The genes coding for all these proteins are present in the genome of $P$. falciparum.

\section{ACTIVITY OF FPIX-INHIBITABLE ENZYMES IN PARASITE CYTOSOL BEFORE AND AFTER DRUG TREATMENT}

We investigated the activity of enzymes reported to be inhibited by FPIX in normal erythrocytes (Zerez et al., 1987). The format was to test enzyme activity in the parasite, using the erythrocyte as a positive control, and then test it again after treatment with CQ.

To verify the effect of FPIX on 6-phosphogluconate dehydrogenase, it was first tested on a commercially available enzyme. At $0.01 \mathrm{U}, 5 \mu \mathrm{M}$ FPIX caused an inhibition of $50 \%$ in enzyme activity at maximal substrate concentration. Results shown in Figure 5A depict the

Fig. 5. - Inhibition of 6-phosphogluconate dehydrogenase activity by FPIX.

Enzyme activity in lysates in absence and in presence of increasing FPIX concentrations was determined as described in Materials and Methods. A. Enzyme activity of erythrocyte lysate was characterized by deriving $\mathrm{Km}(\mu \mathrm{M})$ and $\mathrm{V} \max \left(\times 10^{-3}\right.$ absorbance units $\left./ \mathrm{min}\right)$ values, respectively: Control - (filled circles) $-28.3 \pm 7.1 ; 12 \pm 9$. [FPIX] $=$ $0.5 \mu \mathrm{M}-\bigcirc$ (empty circles) $-23.4 \pm 7.8 ; 10.2 \pm 0.9$. [FPIX] $=$ $1 \mu \mathrm{M}-\boldsymbol{\Delta}$ (filled triangles) $-27.6 \pm 1.9 ; 7.4 \pm 01$. [FPIX] $=$ $2 \mu \mathrm{M}-\triangle$ (empty triangles) $-49.0 \pm 11.1 ; 8.6 \pm 0.6$. B. Enzyme activity in parasite lysate obtained from control and CQ $(10 \mu \mathrm{M})$-treated infected cells. Control - (filled circles) $-8.8 \pm 5.4 ; 4.9 \pm 0.9$. CQtreated $-O$ (empty circles) $-8.2 \pm 3.0 ; 3.1 \pm 0.3$. C. Effect of drug treatment on 6-phosphogluconate dehydrogenase in the compartments of infected cells. Filled bars - uninfected cells; Empty bars - host cell compartment; Grey bars - parasite compartment. Shown are representative results of several similar experiments. Infected erythrocytes were incubated for four hours in absence or in presence of $\mathrm{CQ}$ and $\mathrm{Q}(10 \mu \mathrm{M}$ each). Cells were separated by Percoll gradient and enzyme activity was determined in uninfected cells, in the supernatant of saponin lysed infected cells and in the lysate of free parasites. Activities relative to untreated controls are shown. Notice that only the activity of parasite enzyme is affected. 6-PGA-6-phosphogluconic acid. effect of FPIX on the activity of 6-phosphogluconate dehydrogenase, the second enzyme of the hexose monophosphate shunt (HMS) in erythrocyte cytosol. Symbols depict the experimental results and lines are the best fit to the Michaelis-Menten equation. Increasing [FPIX] first results in non-competitive inhibition - Vmax is reduced - and then the mechanism of inhibition seems to be of a competitive nature, i.e., $\mathrm{Km}$ is increased. Although this observation is rather unusual, higher FPIX concentrations were not tested because they are outside the range of relevance. The overall activity
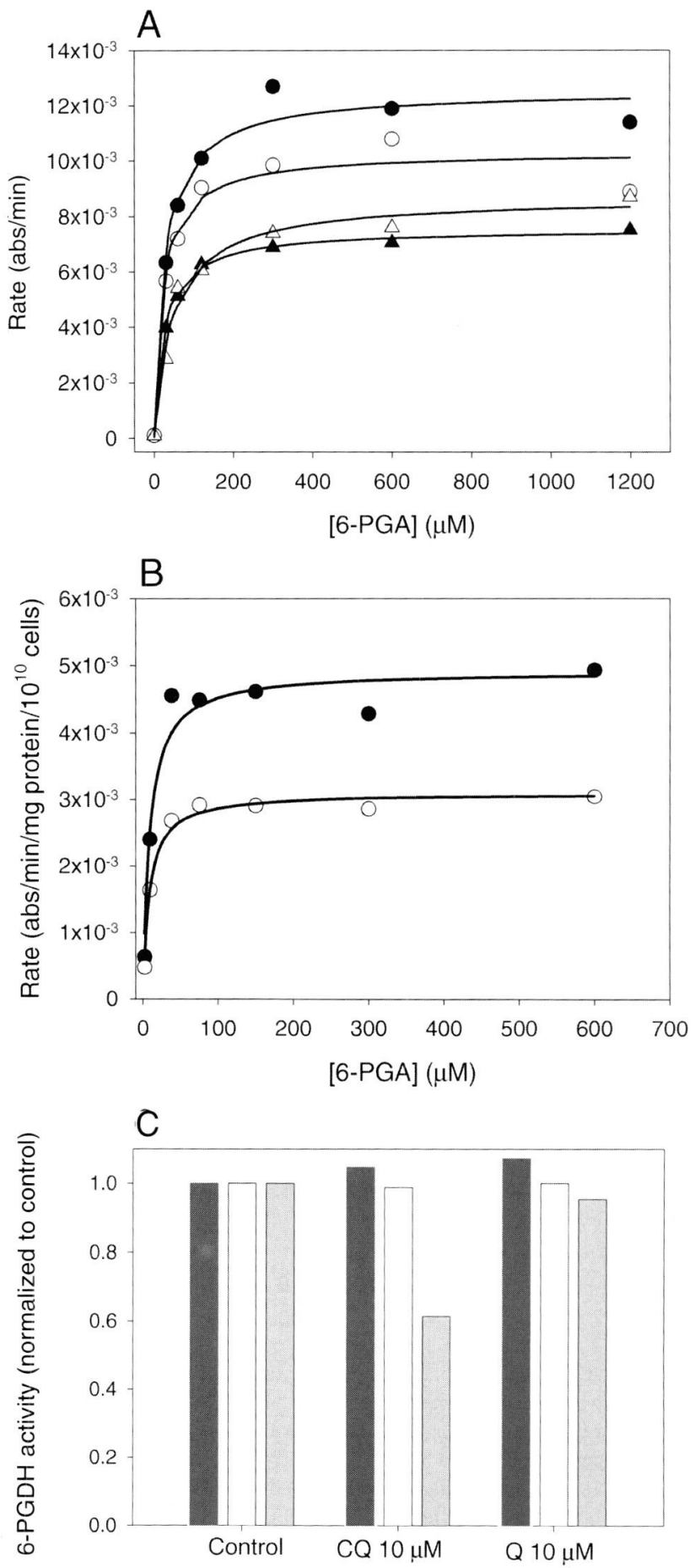
is reduced by $\leq 30 \%$. No inhibition of enzyme activity could be seen in the presence of CQ alone (data not shown). When trophozoite-infected RBC were treated with CQ and the enzyme activity measured in the parasite lysate, a $40 \%$ inhibition of non-competitive nature was observed (Fig. 5B). Results shown in Figure 5C were obtained from the following procedure: parasite cultures at the trophozoite stage were treated with CQ or Q. Infected cells were separated from uninfected by Percoll gradient centrifugation. Enzyme activity was then tested in uninfected cells and in the host and parasite compartments of infected cells. CQ exposure did not affect the enzyme in uninfected cells or in the host compartment of infected cells. Enzyme activity in the parasite compartment was reduced by $40 \%$ (compare with Figure $5 \mathrm{~A}$ ) as would be expected from the putative binding of FPIX to the enzyme. Q had no effect, as would be expected from the lack of FPIX accumulation under the influence of this drug (see Fig. 1B).

As reported by Zerez et al. (1987), we also found that FPIX inhibits the activity of adenylate kinase in uninfected erythrocytes. Inhibition was of the uncompetitive type. $\mathrm{Km}(\mu \mathrm{M})$ increased from $0.19 \pm 0.02$ in control to $0.47 \pm 0.23$ in the presence of $4 \mu \mathrm{M}$ FPIX, and Vmax (in $\times 10^{-2}$ absorbance units $/ \mathrm{min}$ ) declined from $4.45 \pm$ 0.2 to $0.4 \pm 0.01$, respectively. We could not detect any activity of this enzyme in the parasite cytosol, although such activity has been inferred indirectly (Kanaani \& Ginsburg, 1989) and the gene coding for this enzyme can be predicted from the sequencing project of the $P$. falciparum genome: several open reading frames that predictably code for this enzyme have been found on several chromosome: PFD0755c on chromosome 4 (annotated by Sanger), PF10_0086 on chromosome 10 (annotated TIGR), and PlasmoDB using various algorithms for gene prediction could find it on chromosome 8 - chr8.gen_233 (predicted by Genefinder), chr8.glm_ 163 (predicted by GlimmerM) and chr8.phat_150 (predicted by FullPhat).

Whereas FPIX most potently inhibited the activity of the erythrocyte 5'-pyrimidine nucleotidase (Fig. 6), no inhibition of this enzyme in either the host cell or the parasite compartment could be seen after treatment with CQ or with Q. FPIX was also tested on commercially available enzyme $(0.1 \mathrm{mg} / \mathrm{ml})$ and at $5 \mu \mathrm{M}$ inhibited enzyme activity by $80 \%$. These results suggest that this enzyme is the most sensitive to FPIX of those tested.

Aldolase is a key enzyme in the glycolytic pathway, the sole source of metabolic energy for both host cell and parasite (Sherman, 1979). FPIX inhibited a commercially available enzyme $(0.011 \mathrm{unit} / \mathrm{ml})$ by $50 \%$ at $5 \mu \mathrm{M}$. The activity of this enzyme, in normal erythrocytes and in parasite cytosol, was inhibited by FPIX with a $\mathrm{Ki}$ of 5-7 $\mu \mathrm{M}$. However, the activity of the parasite enzyme after CQ treatment was inhibited by only $15 \%$, whereas Q had no effect at all (data not shown).

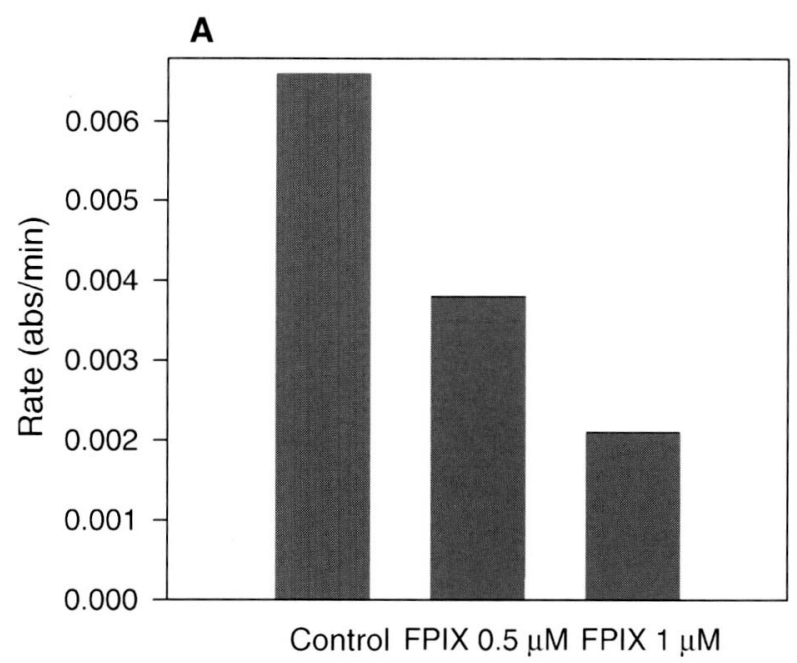

B

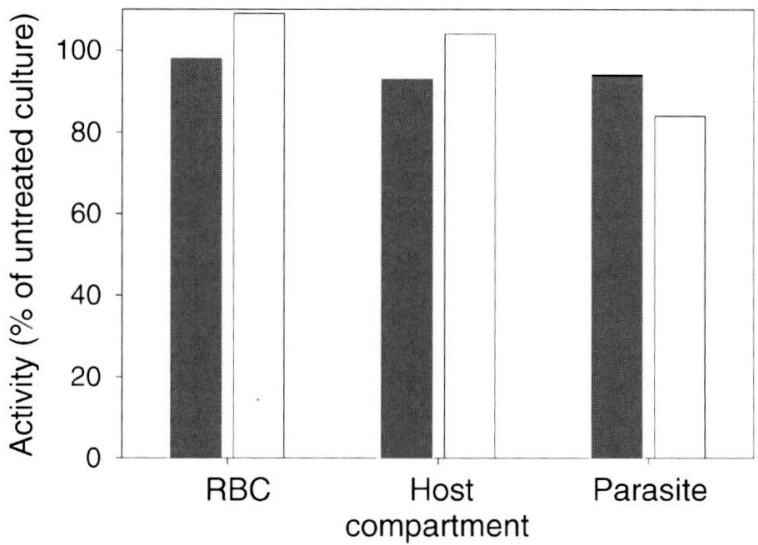

Fig. 6. - Activity of 5'-pyrimidine nucleotidase in normal erythrocytes and in the compartments of control and CQ-treated infected cells.

A. Enzyme activity was determined in lysates of normal erythrocytes using $50 \mu \mathrm{M}$ cytidylmonophosphate (at Vmax), in absence or presence of two concentrations of FPIX. B. Enzyme activity was similarly measured in the lysates of normal erythrocytes (RBC) and in the host cell and parasite compartments of infected cells, after four hours of incubation either in absence of drug or in the presence of $10 \mu \mathrm{M}$ of CQ (filled bars) or $10 \mu \mathrm{M} Q$ (empty bars). \% of activity was calculated with respect to enzyme activity in untreated cells. Shown are representative results of several similar experiments.

\section{BINDING OF FPIX TO PURE PROTEINS}

Several commercially available enzymes, chosen as examples for no particular reason, were tested for their ability to bind FPIX. After a brief exposure to $50 \mu \mathrm{M}$ FPIX, enzymes were run on SDS-PAGE (without DTT) and stained for FPIX and with Coomassie. All enzymes bound FPIX, but comparison of the densities of Coomassie-stained bands to their FPIX-stained counterparts, indicates a variable degree of binding (Fig. 7). Thus, alcohol dehydrogenase, triose phosphate isomerase and $\alpha$-glycerophosphate dehydrogenase bound FPIX more avidly than BSA, cytochrome c oxidase or GSH reductase. Some impurities resolved on the 


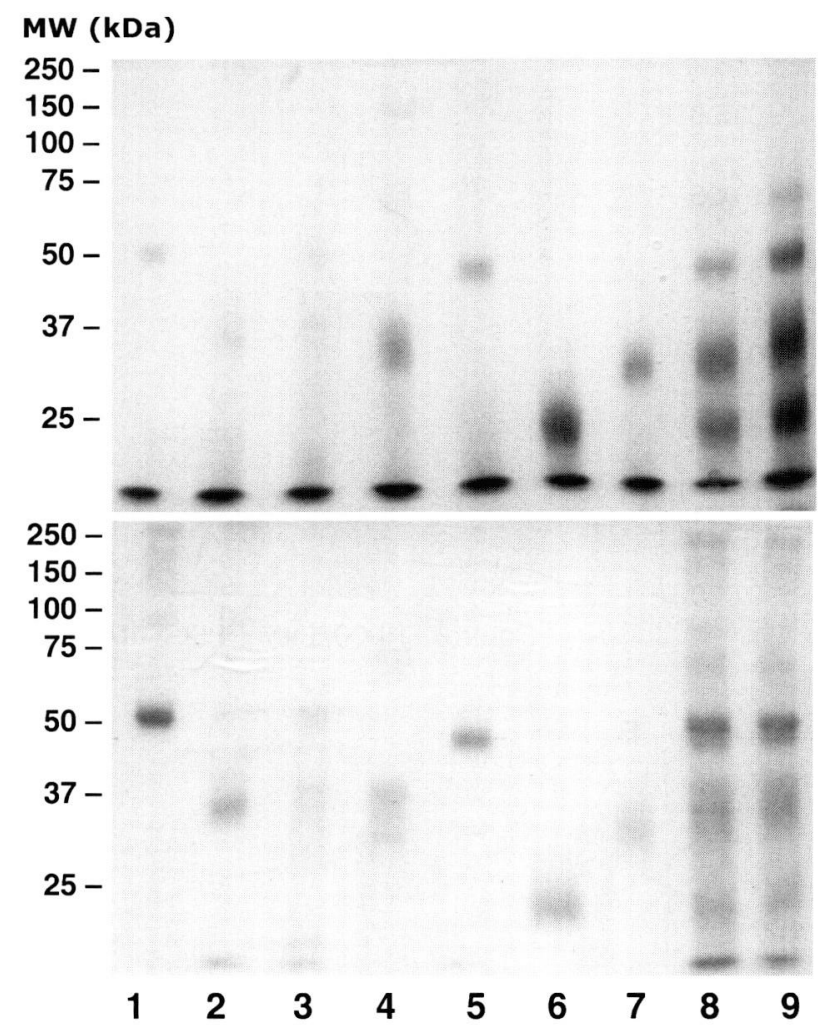

Fig. 7. - Binding of FPIX to various proteins.

Various proteins were incubated with $50 \mu \mathrm{M}$ FPIX, electrophoresed on SDS-PAGE and stained for FPIX (upper panel) and with Coomassie (lower panel). Lane designation: 1 - BSA; 2 - cytochrome c oxidase; 3 - hexokinase; 4 - alcohol dehydrogenase; 5 - GSH reductase; 6 - triose phosphate isomerase; 7 - $\alpha$-glycerophosphate dehydrogenase; 8 - mixture of all proteins incubated with $50 \mu \mathrm{M}$ FPIX; 9 - mixture of all proteins with $350 \mu \mathrm{M}$ FPIX.

Coomassie stained gel did not bind FPIX at all. When all proteins were mixed together, proteins with lower affinity for FPIX such as BSA (lane 1), cytochrome C oxidase (lane 2), and hexokinase (lane 3), could not be seen at low FPIX concentration (lane 8). But they are detectable when FPIX concentration was increased (lane 9). These results clearly indicate that FPIX binds to some proteins with higher affinity than to others, and that the affinity of binding at sub-saturating concentrations determines the partition of FPIX between the different proteins that are present. This conclusion pertains to the differential binding of FPIX to parasite proteins following the treatment of intact cells with $\mathrm{CQ}$ or $\mathrm{AQ}$.

\section{DISCUSSION}

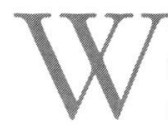

e previously demonstrated that treatment of infected cells with $\mathrm{CQ}$ and $\mathrm{AQ}$, but not $\mathrm{Q}$ or MQ, results in the accumulation of FPIX in the membrane fraction in correlation with parasite killing (Ginsburg et al., 1998; Zhang et al., 1999). We subsequently showed that the accumulation could be due to the inhibition of GSH-dependent degradation of FPIX by CQ and AQ (Famin et al., 1999). Since these drugs, and to a much lesser extent $\mathrm{Q}$ and $\mathrm{MQ}$, inhibit the degradation of BSA-bound FPIX by GSH (Famin et al. 1999), we suspected that undegraded FPIX could also affect protein (enzyme)-dependent processes.

The binding of FPIX can have physiological significance, as it is known to inhibit several erythrocytic enzymes (Zerez et al., 1987) and to regulate protein synthesis through its binding to heme-regulated inhibitor of eukaryotic initiation factor 2 subunit $\alpha$ (eIF$2 \alpha$; Surolia \& Padmanaban, 1991). Here, we have clearly shown that treatment of infected cells with CQ or AQ causes an increase of FPIX association with various parasite proteins in a concentration-dependent manner. Contrary to our previous suggestion that most of the FPIX generated by hemoglobin digestion exits the food vacuole to be degraded by GSH in the parasite's cytosol (Ginsburg et al., 1998), it has been recently shown the vast majority of FPIX is biomineralized into hemozoin (Egan et al., 2002). Although this conforms to the lack of FPIX association with parasite proteins in absence of drug. However, inhibition of FPIX biomineralization by $\mathrm{CQ}$ or $\mathrm{AQ}$ could allow the exit of free FPIX from the food vacuole and its association with the membranes of the infected cells (Zhang et al., 1999). This increase was found to parallel parasite killing where the drugs were used at the same concentrations (Famin \& Ginsburg, 2002). Q and MQ did not cause such an increase although they killed the parasites. The latter two drugs also failed to induce accumulation of undegraded FPIX in the membrane fraction of drug-treated infected cells (Ginsburg et al., 1998; Zhang et al., 1999) probably due to their failure to inhibit the degradation of membrane- and BSA-associated FPIX by GSH (Famin et al., 1999). Both CQ and $A Q$ were effective in these processes. These results underscore again that the mechanistic details of the antimalarial action for $\mathrm{CQ}$ and $\mathrm{AQ}$ differ from $\mathrm{Q}$ and $M Q$, although all these drugs contain the aminoquinoline nucleus (Merkli \& Richle, 1980; Lambros \& Notsch, 1984; Knowles et al., 1984; Webster et al., 1985a, b; Ward et al., 1995).

An alternative mechanism for FPIX destruction has been suggested (Loria et al., 1999), whereby $\mathrm{H}_{2} \mathrm{O}_{2}$ generated during the oxidation of oxy-hemoglobin to methemoglobin in the food vacuole destroys FPIX. At the same time, FPIX reduces $\mathrm{H}_{2} \mathrm{O}_{2}$ due to its peroxidative capacity. Both processes are inhibited by $\mathrm{CQ}$, but much less so by Q or MQ. The weaknesses of this mechanism have been discussed at length elsewhere (Ginsburg \& Krugliak, 1999), and it has been recently shown that parasites develop well in CO-treated erythrocytes (Monti et al., 2002) where $\mathrm{H}_{2} \mathrm{O}_{2}$ is not expected to be produced by hemoglobin degradation. It has 
been shown that $\mathrm{H}_{2} \mathrm{O}_{2}$ enhances the antimalarial action of CQ (Malhotra et al., 1990), but here we have observed that the combined treatment of intact cells with CQ and $\mathrm{H}_{2} \mathrm{O}_{2}$ results in decreased binding of FPIX to proteins. This could raise the question whether druginduced binding of FPIX to parasite proteins is involved in CQ action.

In the present investigation we have shown that various erythrocytic enzymes were inhibited in vitro to variable extents and by different modes of inhibition by FPIX. The same enzymes, except adenylate kinase, were also present in the parasite and similarly inhibited by FPIX. However, when the activities of these enzymes were measured after treatment of infected cells with CQ, they were only marginally affected, except for 6-phosphogluconate dehydrogenase whose activity in the parasite compartment was reduced by $40 \%$. It could be suggested that drug treatment could down-regulate the expression of this enzyme, but this seems rather unlikely given the relatively long half-life of housekeeping enzymes and the short time of drug treatment. The inhibition of 6-phosphogluconate dehydrogenase indicates that a key enzyme of the antioxidant defense of the parasite, this the second enzyme in HMS, is affected by CQ exposure. This result concurs with our previous demonstration that $\mathrm{CQ}$ inhibits the HMS activity of infected cells (Atamna et al., 1994). But such inhibition is also expected if much less GSH would be oxidized when the degradation of FPIX is inhibited by CQ (Ginsburg et al., 1998; Famin et al., 1999). HMS activity provides NADPH that is used to reduce oxidized glutathione by glutathione reductase. Since treatment of intact infected cells with CQ never resulted in a decline in host cell enzyme activity, we conclude that free FPIX does not reach the host cell compartment. We verified this independently by electrophoresis of host cell cytosol and staining of FPIX after drug treatment (data not shown). Thus, binding to proteins or to membranes effectively retains all intact FPIX within the parasite.

The fact that some parasite enzymes can be inhibited by FPIX in vitro, but not when tested after extraction from cells that have been treated with CQ, can be due either to the fact that not enough free FPIX is available for inhibition, or that association of the enzyme with other cytosolic components in the intact cell protects it from the inhibitory effect of FPIX. We have estimated the total level of non-specifically bound FPIX in CQ treated cells to be $156 \mu \mathrm{M}$. This is distributed among all FPIX binding proteins according to their relative affinity for the ligand, as has been shown here for the differential binding of FPIX to a random assortment of proteins (Fig. 8). That 6-phosphogluconate dehydrogenase was found to be equally inhibited both in vitro and in extracts of CQ-treated cells (Fig. 5) suggests that this enzyme has relatively high affinity for FPIX. At the other end of the spectrum was 5'-pyrimidine nucleotidase, which was the most sensitive to FPIX in parasite and erythrocyte extracts vitro, but was not affected by treatment with either CQ or Q (Fig. 6). This enzyme may have a low affinity for FPIX that will be competed-out by other proteins with higher affinity, or can be protected from inhibition through association with other cytosolic proteins. Binding of FPIX to these parasite enzymes is not likely to underlie the antimalarial mode of action of CQ

The second approach for the identification of parasite proteins that bind FPIX was achieved through the binding of parasite cytosolic proteins to hemin-agarose beads, their separation by electrophoresis and subsequent sequencing. Although the binding of FPIX to these proteins may be non-specific, they are singledout from the multitude of other proteins present in the parasite lysate. FPIX is an amphipathic molecule that may indiscriminately affect protein conformation and hence, its effect on enzyme activity may not require specific binding to active or modulating sites. This approach has revealed four additional putative target enzymes: enolase, phosphoglycerate kinase, glyceraldehyde 3-phosphate deydrogenase and L-lactate dehydrogenase, all members of the glycolytic pathway that is the sole generator of ATP in both parasites and host cells (Sherman, 1979). Another glycolytic enzyme, aldolase, was identified by the first approach. Glucose consumption was inhibited by CQ in dose- and stagedependent manner (Yayon et al., 1983), and since glycolysis is the major consumer of glucose, it is suggested that inhibition of glycolytic enzymes by FPIX could be the cause. On the other hand, decreased glucose consumption could result from disruption of ion and $\mathrm{pH}$ homeostasis (Lee et al., 1988) due to permeabilization of membranes by accumulation of undegraded FPIX (Zhang et al., 1999). Parenthetically, a radioiodinated photoreactive analogue of chloroquine was shown to bind specifically to L-lactate dehydrogenase of P. falciparum (Menting et al., 1997). It could well be that this binding is mediated by FPIX. However, it has been recently shown that CQ binds within the $\mathrm{NADH}$ binding pocket of the enzyme, acting as a competitive inhibitor for this critical glycolytic enzyme (Read et al., 1999). But the high $\mathrm{Ki}(1 \mathrm{mM})$ indicates that such inhibition cannot mediate parasiticidal activity.

Hsp70 and Hsp90 were other parasite proteins that bound to hemin-agarose beads. Several Hsp's have been identified in the Plasmodium falciparum genome and some murine parasite species without assignment of a definitive biological role. Hsp70 is expressed in sporozoite, erythrocytic and gametocyte stages (Kumar et al., 1993; Kappes et al., 1993) and has been implicated in invasion of merozoites into uninfected erythrocytes (Tardieux et al., 1998). No allusion to func- 
tional interaction between Hsp70 and FPIX could be found in the literature and it is doubtful that such association would have an immediate consequence for parasite viability.

Hsp90 is one of the most abundant chaperonins in the cytosol of eukaryotic cells and is an obligate component of fundamental cellular processes such as hormone signaling and cell cycle control, steroid receptors, cell cycle kinases, and p53-mediated processes (see Scheibel \& Buchner, 1998 for a review). A single gene ( $p f h s p 80$ ) encoding Hsp90 has been found in the $P$. falciparum genome. It is constitutively expressed in both trophozoite and gametocyte stage parasites (Bonnefoy et al., 1994). The pfhsp86 gene maps within a chromosome 7 segment that is linked to CQ response in a $P$. falciparum cross but its alleles could not predict CQ response (Su \& Wellems, 1994). It may be interesting to investigate if FPIX interferes with one or more of the various functions of Hsp90 as a basis for CQ toxicity.

Elongation factor $1 \alpha$ (EF-1 $\alpha)$ was also retrieved from parasite cytosol by its ability to bind FPIX. EF- $1 \alpha$ is involved in translation of mRNA, in cytoskeletal organization, in activation of the phosphatidylinositol-4 kinase in the regulation of actin polymerization and in modulating the rate of apoptosis (Duttaroy et al., 1998). EF- $1 \alpha$ is encoded by more than one gene in the genome of three malaria parasites, P. knowlesi, P. berghei and P. falciparum (Vikenoog et al., 1998). Interestingly, EF-1 $\alpha$ co-segregates with a CQ-resistant marker in $P$. chabaudi (Carlton et al., 1998). The manifold activities of EF- $1 \alpha$ could well be affected by FPIX, but no evidence for that could be found in the literature.

Gametocytogenesis onset-specific protein (Pfg27/25) is expressed early in the differentiation of gametocytes (Alano et al., 1991; Lobo et al., 1994). It was also retrieved by binding to agarose-hemin beads. Gametocytogenesis is known to increase in response to stress (Sinden et al., 1996). Some non-gametocytocydal antimalarial drugs increase transmission of parasites to mosquitoes (see Butcher, 1997 for review). Subcurative chemotherapy with CQ increases gametocyte production and infectivity to mosquitoes in the rodent malaria P. chabaudi and P. vinckei petteri in vivo (Buckling et al., 1997; Gautret et al., 2000) and gametocytogenesis in P. falciparum in vitro (Buckling et al., 1999). Disruption of infected cells following CQ treatment may release FPIX that could serve as a gametocytogenic signal by activating the factor. However, such binding has probably little or nothing to do with the inhibition of parasite growth by CQ treatment. In conclusion, CQ and AQ cause the accumulation of protein-bound FPIX in the parasite, and binding of FPIX to several enzymes involved in glycolysis may underlie the observed inhibition of this metabolic pathway by CQ (Yayon et al., 1983). Binding to other proteins is probably inconsequential for drug action. We have previously suggested (Ginsburg et al., 1998) that the antimalarial action of CQ (and AQ) is mediated by the accumulation of FPIX in the membrane fraction of the infected cell, that leads to membrane permeabilization and the irreversible perturbation of ion homeostasis and the eventual disruption of cellular metabolism. To elucidate which of these alternative modes of inhibition is of most consequence for parasite death requires further scrutiny.

\section{ACKNOWLEDGEMENTS}

This research (No. 187/98) was supported by a grant from the Israel Science Foundation.

\section{REFERENCES}

Alano P., Premawansa S., Bruce M.C. \& Carter R. A stage specific gene expressed at the onset of gametocytogenesis in Plasmodium falciparum. Molecular and Biochemical Parasitology, 1991, 46, 81-88.

Atamna H., Pascarmona G. \& Ginsburg H. Hexose-monophosphate shunt activity in intact Plasmodium falciparum infected erythrocytes and in free parasites. Molecular and Biochemical Parasitology, 1994, 67, 79-89.

Atama H. \& Ginsburg H. Heme degradation in the presence of glutathione - A proposed mechanism to account for the high levels of non-heme iron found in the membranes of hemoglobinopathic red blood cells. Journal of Biological Chemistry, 1995, 270, 24876-24883.

Beutler E. Red Cell Metabolism. A Manual of Biochemical Methods. Grune \& Stratton. New York, 1984.

Bonnefoy S., Attal G., Langsley G., Tekaia F. \& MercereauPutjalon O. Molecular characterization of the heat shock protein 90 gene of the human malaria parasite Plasmodium falciparum. Molecular and Biochemical Parasitology, 1994, 67, 157-170.

Bray P.G., Janneh O., Raynes K.J., Mungthin M., Ginsburg H. \& Ward S.A. Cellular uptake of chloroquine is dependent on binding to ferriprotoporphyrin IX and is independent of NHE activity in Plasmodium falciparum. Journal of Cell Biology, 1999, 145, 363-376.

Buckling A.G.J., Taylor L.H., Carlton J.M.R. \& Read A.F. Adaptive changes in Plasmodium transmission strategies following chloroquine chemotherapy. Proceedings of the Royal Society, London (Biology), 1997, 264, 553-559.

Buckling A., Ranford-Cartwright L.C., Miles A. \& Read A.F. Chloroquine increases Plasmodium falciparum gametocytogenesis in vitro. Parasitology, 1999, 118, 339-346.

Butcher G.A. Antimalarial drugs and the mosquito transmission of Plasmodium. International Journal of Parasitology, 1997, 27, 975-987.

Carlton J., Mackinnon M. \& Walliker D. A chloroquine resistance locus in the rodent malaria parasite Plasmodium cha- 
baudi. Molecular and Biochemical Parasitology, 1998, 93. 57-72.

Duttaroy A., Bourbeau D., Wang X.L. \& Wang E. Apoptosis rate can be accelerated or decelerated by overexpression or reduction of the level of elongation factor- $1 \alpha$. Experimental Cell Research, 1998, 238, 168-176.

Egan T.J., Combrinck J.M., Egan J., Hearne G.R., Marques H.M., Ntenteni S., Sewell B.T., Smith P.J., Taylor D., VAn SChalkwyk D.A. \& Walden J.C. The fate of haem iron in the malaria parasite Plasmodium falciparum. Biochemical Journal, 2002, 365, 343-347.

Famin O., Krugliak M. \& Ginsburg H. Kinetics of inhibition of glutathione-mediated degradation of ferriprotoporphyrin IX by antimalarial drugs. Biochemical Pharmaco$\log y, 1999,58,59-68$.

Famin O. \& Ginsburg H. Differential effects of 4-aminoquinoline-containing antimalarial drugs on hemoglobin digestion in Plasmodium falciparum-infected erythrocytes. Biochemical Pharmacology, 2002, 63, 393-398.

Francis R.T. Jr \& BeCKer R.R. Specific indication of homeoproteins in polacrylamide gels using a double-staining process. Analytical Biochemistry, 1984, 136, 509-514.

Francis S.E., Sullivan D.J. Jr \& Goldberg D.E. Hemoglobin metabolism in the malaria parasite Plasmodium falciparum. Annual Reviews in Microbiology, 1997, 51, 97-123.

Gautret P., Landau i., Tallhardat L., Miltgen F., Coquelin F., Voza T., Chabaud A.G. \& Jacquemin J.L. The effects of subcurative doses of chloroquine on Plasmodium vinckei petteri gametocytes and on their infectivity to mosquitoes. International Journal of Parasitology, 2000, 30, 1193-1198.

Ginsburg H., Famin O., Zhang J.M. \& Krugliak M. Inhibition of glutathione-dependent degradation of heme by chloroquine and amodiaquine as a possible basis for their antimalarial mode of action. Biochemical Pharmacology, 1998, $56,1305-1313$

Ginsburg H. \& Krugliak M. Chloroquine - some open questions on its antimalarial mode of action and resistance. Drug Resistance Update, 1999, 2, 180-187.

Goldberg D.E. \& Slater A.F. Plasmodium and the infected erythrocyte - the pathway of hemoglobin degradation in malaria parasite. Parasitology Today, 1992, 8, 280-283.

KanaAni J. \& Ginsburg H. Metabolic interconnection between the human malarial parasite Plasmodium falciparum and its host erythrocyte: Regulation of ATP levels by means of an adenylate translocator and adenylate kinase. Journal of Biological Chemistry, 1989, 264, 3194-3199.

Kappes B., Suetterlin B.W., Hofer-Warbinek R., Humar R. \& Franklin R.M. Two major phosphoproteins of Plasmodium falciparum are heat shock proteins. Molecular and Biochemical Parasitology, 1993, 59, 83-94.

Knowles G., Davidson W.L., Jolley D. \& Alpers M.P. The relationship between the in vitro response of Plasmodium falciparum to chloroquine, quinine and mefloquine. Transactions of the Royal Socity of Tropical Medicine and Hygiene, 1984, 78, 146-150.

Krugliak M. \& Ginsburg H. Studies on the antimalarial mode of action of quinoline-containing drugs: time-dependence and irreversibility of drug action, and interactions with compounds that alter the function of the parasite's food vacuole. Life Sciences, 1991, 49, 1213-1219.

Kumar N., Nagasawa H., Sacci J.B. Jr, Sina B.J., Aikawa M., Atkinson C., Uparanukraw P., Kubiak L.B., Azad A.F. \& Hol.ungdale M.R. Expression of members of the heat-shock protein-70 family in the exoerythrocytic stages of Plasmodium berghei and Plasmodium falciparum. Parasitology Research, 1993, 79, 109-113.

Kutner S., Breuer W.V., Ginsburg H., Aley S.B. \& CabantCHIK Z.I. Characterization of permeation pathways in the plasma membrane of human erythrocytes infected with early stages of Plasmodium falciparum: association with parasite development. Journal of Cell Physiology, 1985, $125,521-527$

Lambros C.J. \& Vanderberg J.P. Synchronization of Plasmodium falciparum erythrocytic stages in culture. Journal of Parasitology, 1979, 65, 418-420

Lambros C. \& Notsch J.D. Plasmodium falciparum: mefloquine resistance produced in vitro. Bulletin of the World Health Organization, 1984, 62, 433-438.

LeE P., Ye Z., VAN DYKe K. \& Kirk R.G. X-ray microanalysis of Plasmodium falciparum and infected red blood cells: effect of qinghaosu and chloroquine on potassium, sodium, and phosphorus composition. American Journal of Tropical Medicine and Hygiene, 1988, 39, 157-165.

Lobo C.A., Konings R.N.H. \& Kumar N. Expression of early gametocyte-stage antigens Pfg27 and Pfs16 in synchronized gametocytes and non-gametocyte producing clones of Plasmodium falciparum. Molecular and Biochemical Parasitology, 1994, 68, 151-154

Loria P., Miller S., Foley M. \& Tilley L. Inhibition of the peroxidative degradation of haem as the basis of action of chloroquine and other quinoline antimalarials. Biochemical Journal, 1999, 339, 363-370.

Malmotra K., Salmon D., Le B. \& Vilde J.L. Potentiation of chloroquine activity against Plasmodium falciparum by the peroxidase-hydrogen peroxide system. Antimicrobial Agents and Chemotherapy, 1990, 34, 1981-1985.

Menting J.G., Tilley L., Deady L.W., NG K., Simpson R.J., COWman A.F. \& Foley M. The antimalarial drug, chloroquine, interacts with lactate dehydrogenase from Plasmodium falciparum. Molecular and Biochemical Parasitology, $1997,88,215-224$

Merkli B. \& Richle R.W. Studies on the resistance to single and combined antimalarials in the Plasmodium berghei mouse model. Acta Tropica, 1980, 37, 228-231.

Monti D., Basilico N., Parapin S., Pasini E., Ollitaro P. \& TaraMELLI D. Does chloroquine really act through oxidative stress? FEBS Letters, 2002, 522, 3-5.

Read J.A., Wilkinson K.W., Tranter R., Sessions R.B. \& Brady R.L. Chloroquine binds in the cofactor binding site of Plasmodium falciparum lactate dehydrogenase. Journal of Biological Chemistry, 1999, 274, 10213-10218.

SCheibel T. \& Buchner J. The Hsp90 complex - a super-chaperone machine as a novel drug target. Biochemical Pharmacology, 1998, 56, 675-682.

SHERMAN I.W. Biochemistry of Plasmodium (Malarial Parasites). Microbiological Reviews, 1979, 43, 453-493. 
Sinden R.E., Butcher G.A., Billker O. \& Fleck S.L. Regulation of infectivity of Plasmodium to the mosquito vector. Advances in Parasitology, 1996, 38, 53-117.

Su X.Z. \& Wellems T.E. Sequence, transcript characterization and polymorphisms of a Plasmodium falciparum gene belonging to the heat-shock protein HSP 90 family. Gene, 1994, 151, 225-230.

Surolia N. \& Padmanaban G. Chloroquine inhibits hemedependent protein synthesis in Plasmodium falciparum. Proceedings of the National Academy of the USA 1991, 88, 4786-4790.

Tardieux I., Baines I., Mossakowska M. \& Ward G.E. Actinbinding proteins of invasive malaria parasites and the regulation of actin polymerization by a complex of $32 / 34-\mathrm{kDa}$ proteins associated with heat shock protein $70 \mathrm{kDa}$. Molecular and Biochemical Parasitology, 1998, 93, 295-308.

Vinkenoog R., Speranca M.A., van Breemen O., Ramesar J., Williamson D.H., Ross-MacDonald P.B., Thomas A.W., Janse C.J., Del Portillo H.A. \& Waters A.P. Malaria parasites contain two identical copies of an elongation factor 1- $\alpha$ gene. Molecular and Biochemical Parasitology, 1998, 94, 1-12.

Ward S.A., Bray P.G., Mungthin M. \& Hawley S.R. Current views on the mechanisms of resistance to quinolinecontaining drugs in Plasmodium falciparum. Annals of Tropical Medicine and Parasitology, 1995, 89, 121-124.

Webster H.K., Boudreau E.F., Pavanand K., Yongvanitchit K. \& PANG L.W. Antimalarial drug susceptibility testing of Plasmodium falciparum in Thailand using a microdilution method. American Journal of Tropical Medicine and Hygiene, 1985a, 34, 228-235.

Webster H.K., Thaithong S., Pavanand K., Yongvanitchit K., Pinswasdi C. \& Boudreau E.F. Cloning and characterization of mefloquine-resistant Plasmodium falciparum from Thailand. American Journal of Tropical Medicine and Hygiene, 1985b, 34, 1022-1027.

Yayon A., Vande Waa J.A., Yayon M., Geary T.G. \& Jensen J.B. Stage-dependent effects of chloroquine on Plasmodium falciparum in vitro. Journal of Protozoology, 1983, 30, 642-647.

Yayon A., Timberg R., Friedman S. \& Ginsburg H. Effects of chloroquine on the feeding mechanism of the intraerythrocytic human malarial parasite Plasmodium falciparum. Journal of Protozoology, 1984, 31, 367-372.

Zerez C.R. \& TANaka K.R. A continuous spectrophotometric assay for pyrimidine-5'-nucleotidase. Analytical Biochemistry, 1985, 151, 282-285.

Zerez C.R., HSEIH J.W. \& TANAKA K.R. Inhibition of red blood cell enzymes by hemin: a mechanism for hemolysis in hemoglobinopathies. American Journal of Tropical Medicine and Hygiene, 1987, 100, 329-338.

Zhang J.M., Krugliak M. \& Ginsburg H. The fate of ferriprotorphyrin IX in malaria infected erythrocytes in conjunction with the mode of action of antimalarial drugs. Molecular and Biochemical Parasitology, 1999, 99, 129-141.

Reçu le 12 septembre 2002 Accepté le 19 décembre 2002 